\title{
DEVELOPING CRITICAL THINKING SKILLS THROUGH MICROTEACHING
}

\author{
Ika Wahyuni Lestari \\ Mubammadiyah University of Yogyakarta \\ ikawahyuni_11@umy.ac.id
}

\begin{abstract}
This study aimed to explore how microteaching improved the students' critical thinking skills. The method used was qualitative research. The procedure of collecting the data was assigning 20-minute microteaching to nine groups of preservice teachers over nine weeks of teaching and learning process. In a group of two to three, they were asked to demonstrate their understanding on how to teach English to young learners based on a given topic. Peer feedback and teacher feedback were also given as a post-activity. Two preservice teachers were interviewed to explore their views on how the microteaching model influenced their critical thinking. The results showed that all stages of the microteaching model - the preparation and planning, the 20 minutes microteaching, peer feedback, and teacher feedback - enhanced their critical thinking skills.
\end{abstract}

Keywords: microteaching, peer feedback, teacher feedback, critical thinking

\section{A. INTRODUCTION}

icroteaching has become a widely applied method to prepare students to practical
skills. Since first introduced by Allan (1990s) to prepare students in the clinical
practice, microteaching has also applied in teacher education through which teacher candidates - students who are taking a teacher training program - are exposed to experiences teaching a mini lesson to their peers. Göçer (2016) defined microteaching as "a concise method through which teachers can practice teaching strategies, judge their own effectiveness, and receive immediate feedback" (p.44). From this definition, it indicated that teacher candidates who are conducting microteaching will undergo several stages of activities, such as teaching practice, selfreflection, and feedback. Microteaching enables teacher candidates to bring the theories they have learnt into practice through a planned simulation. It also trains their teaching skills and confidence by teaching their peers (Ismail, 2011).

Prior studies have reported the benefits microteaching offers. Al-Humaidi and Abu-Rahmah (2015) conducted an experimental study to 24 Omani student-teachers to explore the effectiveness of a proposed model of microteaching applied in Sultan Qaboos University. Using a checklist as the instrument of the study, the participants were asked to assess their peers' teaching performance in the microteaching. The findings showed that the proposed model of the microteaching was effective for enhancing student-teachers' teaching performance. In terms of the improvement on language skills, Ismail (2011) found that improvement of language skills can be achieved by giving feedback and comments their peers gave after the microteaching practice. In the context of microteaching in teacher education, Arsal (2015) conducted an experimental study to 70 pre- 
service language teachers in Turkey to find out whether microteaching had impacts on their critical thinking disposition. The findings showed that microteaching improved their critical thinking dispositions.

This study reported a microteaching model applied in an English language teacher training institution in Yogyakarta, Indonesia. Although prior studies had been conducted to investigate the effectiveness and benefits of microteaching (Ismail, 2011; Al-Humaidi \& Abu-Rahmah, 2015; Arsal, 2015), the present study shed new light on the practices of microteaching as it explored more deeply on the preservice teachers' first experiences in performing microteaching and how their first experienced improved their critical thinking skills. Different from the microteaching model applied in the three prior studies which was an individual task, that of the present study was conducted in groups. Therefore, the results of the present study are expected to give different overview on how grouped microteaching could also be applied as an initial stage to prepare preservice teachers to have their own individual teaching.

Although microteaching is a simulation in that teacher candidates teach their peers who act as students, this simulated instruction may challenge students. Despite the opportunities microteaching provides in preparing teacher candidates in their future teaching, the experience in microteaching may not be easy as many teacher candidates find it as the first teaching experience and the impacts on this first experience are quite significant (Bilen, 2015). Therefore, applying appropriate microteaching model to prepare teacher candidates' teaching is crucial. It is also imperative to apply microteaching model which can help teacher candidates develop their critical thinking skills.

\section{B. REVIEW OF LITERATURE}

\section{Critical Thinking}

Critical thinking skills are important skills students must master. Rather than focusing on memorizing and simply recalling what they have learnt, taking into accounts what they have learnt as considerations to do something is more important. Critical thinking is skills required by students in order to develop their knowledge and understanding. Ennis (as cited in Kusumoto, 2018) defined critical thinking as reflective thinking on what someone believes or does along with its justifications. From this definition, it indicated that when students think critically, they can justify what they believe or do. Critical thinking involves skills to analyze and evaluates something in order to enhance it (Paul \& Elder as cited in Arsal, 2015). Critical thinking is also considered as skills to identify problems, to analyze specific circumstances, to draw solutions to a problem, and to evaluate results (Minakova, 2014). 


\section{Volume 5, Number 02, December 2019}

Krathwohl (2002) elaborated the cognitive process dimension of the revised Bloom's taxonomy. The revised taxonomy consists of six levels: remembering, understanding, applying, analyzing, evaluating, and creating. The last three levels - analyzing, evaluating, and creating - showed cognitive processes which lead to higher order of thinking, including critical thinking. In analyzing, students should be able to relate one part to another and to the whole structure and purpose. Meanwhile, in evaluating, students should be able to make judgments based on given standards or criteria by checking and critiquing. Lastly, in creating, students should be able to generate, plan, and produce original products. It can be concluded that students who can go through the three cognitive processes can be considered having critical thinking skills.

\section{The Microteaching Model Applied in this Study}

This paper aimed at reporting the microteaching model applied in one teacher training institution in Yogyakarta, Indonesia and how it developed the pre-service teachers' critical thinking skills. The microteaching was conducted in an English for Young Learners class offered to English Language Education Department students as an elective course. Students enrolling this course varied from sophomores to seniors. The course was conducted over sixteen meetings, nine of which was designed to assign students to do microteaching for twenty minutes in a group of two to three. Different from other typical microteaching practices which are conducted as an independent course in teacher education and an individual task, the microteaching in the present study was designed as one of the in-class activities applied in the English for Young Learners course. Through the microteaching, the pre-service teachers were assigned to show how theories of a specific topic were brought into practice. The microteaching model applied in this course consisted of four stages as shown in Figure 1.

\section{Figure 1. The Microteaching Model Applied in English for Young Learners Course}

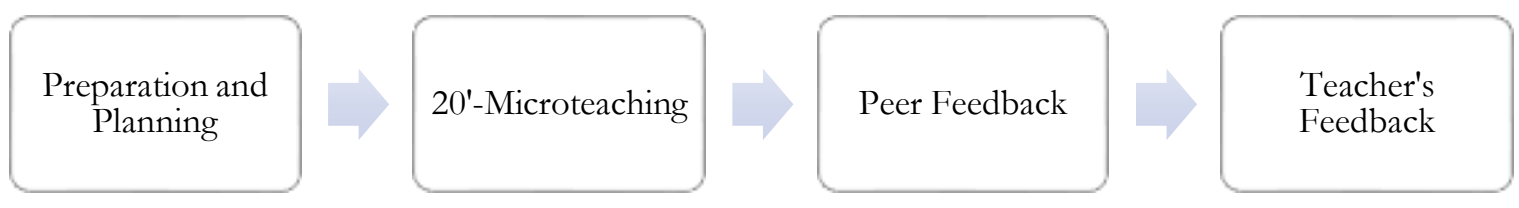

The first step of the applied microteaching model was preparation. In this stage, the preservice teachers were assigned to read a specific chapter or topic which would be discussed in class. They needed to comprehend a theory on how to teach English to young learners. After 
learning the theory through reading, they were required to make a video lecture in group. The video was created to explain the material they learnt in the reading stage. Through this activity, the preservice teachers had an experience on explaining materials to their peers through a video lecture they uploaded prior to the microteaching. This activity was also designed to prepare the preservice teachers to be able to explain their understandings on materials they learnt to others.

When the preservice teachers had prepared their comprehension on how to teach young learners, they were asked to plan their microteaching. They set the learning goal, the grade of the students they were going to teach, the materials, teaching media they would use, the activities they were going to do in each teaching stage, and the assessment technique. As the microteaching was conducted in groups, students were also in charge of distributing tasks for each group member in the microteaching. This activity was in line with the microteaching model proposed by Al-Humaidi and Abu-Rahmah (2015). In their proposed model, the preservice teachers had to make planning and feedback where student-teachers were assigned to prepare a lesson and got feedback from the instructor on the lesson plan they prepared.

The second stage of the microteaching applied in English for Young Learners course was microteaching. This microteaching was conducted for 15 to 20 minutes for each group in front of approximately 20 students enrolling the course. Bilen (2015) also explained that in microteaching, the preservice teachers make a planning on their teaching to teach a specific material within 10-15 minutes before 10-15 classmates and a teacher. Prior to the microteaching, the preservice teachers made an agreement with their classmates who also served as their students to create a closely authentic classroom situation. The preservice teachers informed the grade of the students they should act like, the nature of the material they would teach whether it was introduced the first time, or it was a review on the already discussed material, and the like. The 20-minute microteaching covered the three teaching stages: pre-teaching, whilst teaching, and post teaching.

In this microteaching activity, different roles were played. The classmates acted as students taught by the student teachers. At the same time, the classmates also became observers for the performance of the preservice teachers. Göçer (2016) claimed that when observing other teacher candidates' teaching performance, other students can learn different learning strategies. While pretending to be their students, the classmates are also required to observe the good side as well as aspects to improve from the preservice teachers. Al-Humaidi and Abu-Rahmah (2015) asserted that in microteaching stage, student-teachers are teaching their peers while also being observed by them at once. Lee, Cho, and Lee (2017) stated that through microteaching, preservice teachers can explore various teaching techniques from their peers' teaching as well as evaluate their own teaching. Meanwhile, the supervising teacher mainly became a complete observer during the 20- 


\section{Volume 5, Number 02, December 2019}

minute teaching and learning process and did not make any interaction either with the studentteachers or the students. While observing, the supervising teacher took notes on the good aspects the student teachers had to maintain and the ones which required improving.

The activity following the 20-minutes microteaching was peer feedback. Five students who pretended to be students were welcomed to give feedback and comments on the student teachers' teaching performance. They were asked to mention the good and the need-improvement aspects of the applied teaching. Feedback and comments could address any aspects of teaching; however, those related to the material which would be discussed were prioritized. While the classmates were giving feedback and comments, the preservice teachers were taking the comments to reflect on and evaluate their teaching. In this stage they were not allowed to respond to the feedback and comment. In their proposed model, Al-Humaidi and Abu-Rahmah (2015) also designed a postmicroteaching activity in which student teachers' peers gave feedback and reflection on the student teachers' teaching performance.

After the classmates gave their feedback and comments on the microteaching, the superviser also shared the notes she took while observing the microteaching. Firstly, she mentioned some good points related to good teaching that the preservice teachers had applied in the microteaching. Afterwards, she also pointed out some aspects that the student teachers needed to improve and those which were not in line with theories on teaching English to young learners. From this feedback, the teacher could also explain the students how to teach young learners. Therefore, this session could also be used as an input session to discuss materials.

In addition to the notes from the observation, she also addressed the feedback and comments given by the classmates. In this part, the teacher clarified the comments which were not suitable to the theories of teaching young learners. Therefore, both the student-teachers and the students who gave feedback could evaluate their understanding. Aydin (2013) found that the feedback and comment given by a supervising teacher and peers could be used as an evaluation. The supervising teacher also clarified the points brought up in the peer feedback session to the preservice teachers. She found it important as sometimes preservice teachers and their classmates had different perception and understanding on some points of teaching. These different views were brought up as a discussion topic in which all students were invited to share their thoughts and knowledge to address the problem. At last, she wrapped up the meeting by explaining the materials to all students.

\section{METHOD}


Ika Wahyuni Lestari, Developing Critical Thinking...

The qualitative study was conducted to understand how the microteaching model applied in English for Young Learners course influenced preservice teachers' critical thinking skills. Two preservice teachers, Melati and Vina (pseudonyms) enrolling this course were interviewed as the participants of the study. The aim of this interview was to explore their views on how each step in the microteaching model influenced their critical thinking skills. These two preservice teachers were selected based on their active participation in the in-class discussion and the fact that doing microteaching was their first experience. Therefore, it was expected that this first experience could raise various views on the microteaching. The two participants were first asked their willingness to participate in the study and they stated they were glad to be interviewed. The interview was conducted after the course was over. It was expected that the teaching and learning process they had just attended helped them recall their microteaching experience.

\section{FINDINGS AND DISCUSSION}

\section{The Influence of Microteaching Model on the Critical Thinking Skills}

From the interview conducted to two preservice teachers, it was found out that the four stages of the applied microteaching model enhanced their critical thinking.

Critical Thinking Skills in Preparation and Planning; In preparing and planning the microteaching, Melati and Vina stated that they had to think critically. For example, when planning the teaching, Melati needed to think critically to plan the lesson.

This is my first experience. I have many things to prepare: the teaching plan, the objective, [and] the teaching strategies. So, we must think critically, for example when I want to teach listening and speaking, I have to think how to teach listening and speaking well. It really improves my critical thinking, particularly in pedagogy. (Melati)

Echoing to Melati's opinion, Vina also stated that when she prepared her microteaching, she thought critically in selecting appropriate learning media and materials to her students' age.

... for example, when selecting a song as a learning medium, [questioning] is it suitable for

the children? Is the material too difficult or too easy? (Vina)

Melati also recalled her experience when she thought about the number of words, she would teach to her students based on the theory on teaching English to young learners she read.

From the preservice teachers' opinions, it indicated that microteaching particularly the preparation and planning stage might help them think critically. Through critical thinking, they interpreted theories they have read and brought them into practice by planning their teaching and made sure that all aspects of the teaching they planned were related one and another. This finding showed the pre-service teachers had analysis cognitive domain which characterizes critical thinking. 


\section{Volume 5, Number 02, December 2019}

Krathwohl (2002) explained that in analyzing, students should be able to relate one part to another and to the whole structure and purpose

Critical Thinking Skills in the 20-minute Microteaching; When doing her microteaching, Vina evaluated and learnt from her teaching.

It was my first experience [doing microteaching]. I finally knew how to teach children. When I was standing before my classmates, I knew how it felt to teach, I knew how to explain materials to students although the situation was different as it was a real teaching. (Vina)

From that experience, she could evaluate her teaching in order that she could make improvement one day. Critical thinking involves skills to analyze and evaluates something in order to enhance it (Paul \& Elder as cited in Arsal, 2015).

Critical Thinking Skills in Peer Feedback; In the feedback session, Melati and Vina recalled that they were given feedback by their classmates. This activity somehow trained their critical thinking skills. When they got feedback, they evaluated their teaching and found out that what they had planned was not necessarily suitable with theories.

I finally know that what we tanght was not entirely suitable although we believed we had made good preparation. For example, back then I used ice breaking. It turned out it was not in line with the material we taught to the students. (Vina)

From this feedback, Vina evaluated her teaching and she admitted that her peer's feedback was right.

Melati had a different view on the feedback she received in that she did not take it for granted. She evaluated the feedback she received by thinking whether it was in line or not.

When my classmates gave me feedback, I did not agree on it directly. I thought about it first to see whether it was in line with my teaching plan or not. I also thought if the feedback. was in line with theories or not. (Melati)

Her beliefs that she should not take everything for granted when her peers gave feedback trained her critical thinking in that she could select the feedback which was relevant and that which was not.

Besides receiving feedback from their peers, Vina and Melati also gave feedback to their peers who performed as teachers.

When my friend was teaching, I observed from the beginning to the end. Then, I thought whether their teaching was related between one activity and another. (Vina)

In this activity, classmates who pretended to be students should make judgment on their peers' performance as well as be able to justify their feedback. Therefore, this activity might help them improve their critical thinking skills. It is in line with Ennis who defined critical thinking as 
reflective thinking on what someone believes or does along with its justifications (as cited in Kusumoto, 2018).

Critical Thinking Skills in Teacher Feedback; Besides classmates, the supervising teacher also gave feedback for her students who served as the teacher in the microteaching stage. From the feedback she gave to the student teachers, they could think critically by evaluating their teaching and planning better teaching in the future.

What I thought to be right was not necessarily right. There was a mistake in that [as shown by the supervising teacher]. From that feedback, I thought how to avoid the same mistake in the future. (Melati)

The finding resonated Paul and Elder who asserted that critical thinking involves skills to analyze and evaluates something in order to enhance it (as cited in Arsal, 2015).

\section{E. CONCLUSION AND RECOMMENDATIONS}

This study reported a microteaching model applied in English for Young Learners course in a teacher training institution in Yogyakarta, Indonesia over nine weeks and how it helped the preservice teachers develop their critical thinking skills. The microteaching model was done in four steps: (1) preparation and planning, (2) 20-minute microteaching, (3) peer feedback, and (4) teacher feedback. From the interview with two preservice teachers joining the microteaching, it was found out that the four steps in the microteaching model could help them enhance their critical thinking. Although the microteaching model in the present study was solely a part of activities done in one course, it is expected that it can contribute to the development of microteaching method by providing an initial overview that microteaching is worth applying in teacher education. Also, the present study reported another form of microteaching which was performed in groups. The findings showed that microteaching as a part of classroom activities could enhance student teachers' critical thinking; therefore, it is recommended that teachers can design a classroom activity utilizing microteaching method.

\section{REFERENCES}

Al-Humaidi, S. H., \& Abu-Rahmah, M. I. (2015). Enhancing microteaching at Sultan Qaboos University. Studies in English Language Teaching, 3(1), 28-40.

Arsal, Z. (2015). The effects of microteaching on the critical thinking dispositions of pre-service teachers. Australian Journal of Teacher Education (Online), 40(3), 140-153.

Aydin, I. S. (2013). The effect of micro-teaching technique on Turkish teacher candidates' perceptions of efficacy in lesson planning, implementation, and evaluation. Electronic Journal of Social Sciences, 12(43), 67-81. 
Bilen, K. (2015). Effect of micro teaching technique on teacher candidates' beliefs regarding Mathematics teaching. Procedia-Social and Behavioral Sciences, 174, 609-616.

Göçer, A. (2016). Assessment of the opinions and practices of student teachers on micro-teaching as a teaching strategy. Acta Didactica Napocensia, 9(2), 33-46.

Ismail, S. A. A. (2011). Student teachers' microteaching experiences in a preservice English teacher education program. Journal of Language Teaching and Research, 2(5), 1043-1051.

Krathwohl, D. R. (2002). A revision of Bloom's taxonomy: An overview. Theory into practice, 41(4), 212-218. doi: 10.1207/s15430421tip4104_2

Kusumoto, Y. (2018). Enhancing critical thinking through active learning. Language Learning in Higher Education, 8(1), 45-63. doi:10.1515/cercles-2018-0003

Lee, Y. J., Cho, H. S., \& Lee, K. C. (2017). Promoting self-efficacy through microteaching in a flipped classroom in US teacher education. 한국산학기술학회 논문지, 18(8), 221-230.

Minakova, L. Y. (2014). Critical thinking development in foreign language teaching for nonlanguage-majoring students. Procedia-Social and Behavioral Sciences, 154, 324-328. 